La União Nacional dos estudantes (UNE) ante el juzgamiento y la prisión de Lula da Silva

Fernando Romero Wimer - Paula Fernández Hellmund

páginas / año 10 - n 23 Mayo - Agosto / ISSN 1851-992X/ pp.61-83/ 2018

http://revistapaginas.unr.edu.ar/index.php/RevPaginas

\title{
La União Nacional dos estudantes (UNE) ante el juzgamiento y la prisión de Lula da Silva
}

\author{
La União Nacional dos estudantes (UNE) before the judgment and \\ prison of Lula da Silva
}

\author{
Fernando Romero Wimer \\ Universidade Federal da Integração Latino-Americana (Brasil) \\ Grupo Interdisciplinar de Estudos e Pesquisa sobre Capitais Transnacionais, \\ Estado, classes dominantes e conflitividade na América Latina e Caribe \\ Centro Interdisciplinario de Estudios Agrarios, \\ Universidad de Buenos Aires, \\ Colectivo de Estudios e Investigaciones Sociales \\ fernando.romero@unila.edu.br \\ fernandogromero@gmail.com
}

Paula Fernández Hellmund

Universidade Federal da Integração Latino-Americana (Brasil) Grupo Interdisciplinar de Estudos e Pesquisa sobre Capitais Transnacionais, Estado, classes dominantes e conflitividade na América Latina e Caribe Colectivo de Estudios e Investigaciones Sociales Observatorio Social de América Central e Caribe paula.fernández@unila.edu.br

\footnotetext{
Resumen

Este texto tiene por objetivo describir y analizar el accionar de las organizaciones estudiantiles universitarias brasileñas frente al juzgamiento y la prisión del ex presidente Luiz Inácio "Lula" Da Silva. La investigación recoge, como antecedentes significativos para entender este proceso, los cambios en el campo universitario de la última década y media y las relaciones de la União Nacional dos Estudantes (UNE) con los gobiernos de Lula y Dilma Rousseff, y el Partido dos Trabalhadores (PT).
}

Palabras Clave

Movimiento estudiantil; Brasil; Lula Da Silva; Universidad; Estado

Esta obra está sujeta a la Licencia Reconocimiento-NoComercial-CompartirIgual 4.0 Internacional de Creative Commons. http://creativecommons.org/licenses/by-nc-sa/4.0/ (cc) BY-NC-SA 


\title{
La União Nacional dos estudantes (UNE) ante el juzgamiento y la prisión de Lula da Silva
}

\begin{abstract}
The text aims to describe and analyze the actions of Brazilian university student organizations in the face of the trial and imprisonment of former President Luiz Inácio "Lula" Da Silva. The research gathers, as significant antecedents to understand this process, the changes in the university field of the last decade and a half and the relations of the União Nacional dos Estudantes (UNE) with the governments of Lula and Dilma Rousseff, and Partido dos Trabalhadores (PT).
\end{abstract}

Keywords

Student movement; Brazil; Lula Da Silva; University; State

\section{Introducción}

Este estudio tiene por objetivo describir y analizar el accionar de las organizaciones estudiantiles universitarias brasileñas frente al juzgamiento y la prisión del ex presidente Luiz Inácio “Lula” Da Silva. La investigación recoge, como antecedentes significativos para entender este proceso, los cambios en el campo universitario de la última década y media y las relaciones de la União Nacional dos Estudantes (UNE) con los gobiernos de Lula y Dilma Rousseff, y el Partido dos Trabalhadores (PT). Consideramos pertinente abordar el objeto de estudio a través de diferentes publicaciones estudiantiles, panfletos, documentos, noticias de la prensa y, complementariamente, recurrir a la consulta de militantes que a la vez que resultaron fuente de información, contribuyeron a la interpretación de los hechos.

Primeramente, se expone un marco teórico general que guía la investigación $\mathrm{y}$, en segundo lugar, se presenta un recorrido por los principales hitos que marcaron la historia del movimiento estudiantil universitario brasileño durante el siglo XX. Posteriormente, se examinan como ejes interpretativos: el proceso político, la composición social del estudiantado, el nivel de participación e involucramiento de las organizaciones estudiantiles, las formas de acción colectiva adoptadas, y los factores de movilización social.

\section{Una problematización teórica sobre la universidad y los estudiantes universitarios}

A fin de evitar una formulación meramente descriptiva de los hechos y procesos que investigamos, establecemos inicialmente las definiciones conceptuales y la perspectiva teórica que guía nuestro estudio. Estas aserciones constituyen los puntos de partida para examinar la cuestión universitaria y estudiantil.

Consideramos que el análisis de la universidad como escenario desde dónde se desarrollan las prácticas sociales y se definen las identidades de los sujetos debe pensarse en relación con la organización institucional del Estado y el modo de producción capitalista.

Entendemos que el Estado es preponderantemente una instancia de dominación de una clase sobre otra; por lo cual, es también una estructura de 


\section{Fernando Romero Wimer - Paula Fernández Hellmund}

legitimación de las relaciones sociales imperantes en una determinada época histórica. ${ }^{1}$ Para la constitución de ese entramado de dominación, la clase dominante se apoya en una serie de aparatos para atender los aspectos burocráticoadministrativos, militar-represivos e ideológicos. ${ }^{2}$

En toda sociedad, la universidad -tanto pública como privada- forma parte de los aparatos ideológicos de Estado, y como tal contribuye a la producción y reproducción de ideas que, sobre todo, terminan resultando funcionales al orden establecido. No obstante, la subordinación social en que se encuentran la mayoría de los docentes, investigadores y trabajadores administrativos y de maestranza de la educación superior, así como la mayoría de los estudiantes universitarios por su condición de capa sensible a los problemas sociales, hace de la Universidad un campo de contradicciones, conflictos y disputas contra la dominación y la legitimación de ese orden ${ }^{3}$.

La estructuración dependiente del capitalismo latinoamericano profundizó dos rasgos sustantivos de las universidades: a) las dificultades de acceso la educación superior de los sectores no dominantes y b) una fuerte influencia de los intereses imperialistas sobre el desarrollo científico y tecnológico.

La primera de estas características no es exclusiva de los países dependientes, sólo adquiere un perfil particular por el peso numérico de los contingentes sociales excluidos. El fenómeno refiere a la exclusión clasista, racista y meritocrática del sistema universitario. ${ }^{4}$ En América Latina, las instituciones superiores adoptan distintas formas de clausura a las personas indígenas, negras, mestizas, y pobres.

El segundo rasgo está relacionado con el desarrollo del capitalismo a nivel global y el predominio del pensamiento científico y técnico de las principales potencias como poder legitimador sobre y contra los saberes y los intereses locales y nacionales de los territorios que se estructuraron en forma dependiente. ${ }^{5}$ Estas influencias determinaron el contenido y la dirección de los estudios universitarios en América Latina. Específicamente en el caso de Brasil, la permanente transformación de las relaciones de dominación, contradicción, subordinación y asociación en el plano internacional también influyeron, en los últimos años, en redefiniciones en la configuración de la relación entre la extracción de plusvalía

\footnotetext{
1 Fernando Gabriel Romero. "Sobre los estudiantes universitarios y movimiento estudiantil: problemas teóricos conceptuales", en Fernando Gabriel Romero (Compilador). Los estudiantes. Organizaciones y luchas en Argentina y Chile. Bahía Blanca, Ediciones en Colectivo, 2009, p. 10.

2 Marta Harnecker. Los conceptos elementales del materialismo histórico. México, Siglo XXI, 1999 [1971], pp. 127-132.

3 Fernando Gabriel Romero, Iván Grasso y Eugenio Monforte. "El movimiento estudiantil universitario bahiense desde el segundo gobierno de Menem a la caída de De la Rúa (1995-2001)", en Pablo Bonavena, Juan Sebastián Califa y Mariano Millán (Compiladores). El movimiento estudiantil argentino. Historias con presente. Buenos Aires, Ediciones Cooperativas, 2007, p. 273.

${ }^{4}$ Pierre Bourdieu y Jean Claude Passeron. Los estudiantes y la cultura. Barcelona, Labor, 1967.

${ }^{5}$ José Carlos Mariátegui. Siete ensayos de interpretación sobre la realidad peruana. Buenos Aires, El Andariego, 2005 [1928], p. 75.
} 


\section{La União Nacional dos estudantes (UNE) ante el juzgamiento y la prisión de Lula da Silva}

dentro y fuera de sus fronteras, y la reorganización y expansión del sistema de enseñanza superior.

Asimismo, queremos establecer una aproximación primaria a la comprensión del sujeto estudiantil universitario. Un primer elemento saliente es que se manifiestan en el estudiantado los intereses y contradicciones de clases y fracciones de clase que se desenvuelven en el interior de la sociedad, en particular los intereses y aspiraciones sociales de las clases de las cuales los estudiantes provienen. ${ }^{6}$ Una segunda formulación a tener en cuenta es que la conformación heterogénea del estudiantado universitario precisa un análisis que permita ver esa composición social a la vez que se indaga sobre las diferentes experiencias colectivas de organizaciones y grupos. Esta tarea no está exenta de dificultades a la hora de correlacionar datos sobre los intereses, los objetivos, la autoidentificación y el origen social del estudiantado.

\section{El desarrollo histórico del movimiento estudiantil universitario brasileño}

Por movimiento estudiantil universitario brasileño nos referimos a las prácticas colectivas con continuidad histórica, con cierta coherencia interna en términos de intereses compartidos, objetivos comunes y un sentido de pertenencia e identidad entre sus integrantes. En este sentido, este estudiantado universitario consiguió aglutinarse siguiendo reivindicaciones estudiantiles específicas y expresando luchas políticas más generales orientadas hacia determinados gobiernos y el sistema político. ${ }^{7}$

Si bien se gestaron asociaciones y organizaciones estudiantiles al calor del lento avance de la educación superior brasileña en el siglo $\mathrm{XX}^{8}$, la UNE se fundó recién en 1937, 17 años después de la fundación de la Universidade de Rio de Janeiro (UFRJ), la primera institución de educación superior que recibió el nombre de universidad. ${ }^{9}$

En la década de 1960, la UNE -aun cuando fue declarada ilegal luego del golpe de Estado de 1964 y se organizó clandestinamente- fue una de las organizaciones que estuvo a la cabeza de la lucha contra la dictadura militar. En 1966, la UNE decretó el 22 de septiembre como Día Nacional de Lucha contra la Dictadura y se registraron movilizaciones en distintas ciudades brasileñas, siendo reprimidos violentamente. Un día después, en Rio de Janeiro, se produjo la llamada "Masacre de

\footnotetext{
${ }^{6}$ León Trotsky, "La intelligentsia y el socialismo" [1910], en: León Trotsky, Literatura y revolución. Escritos sobre arte y cultura, escritores y crítica literaria. Buenos Aires, Antídoto, 2004, p. 174.

${ }^{7}$ Fernando Gabriel Romero. "Sobre los estudiantes...", op. cit., p. 15.

${ }^{8}$ Cidara Loguercio Souza y Maria Elly Herz Genro, "Memorias de académicos del sur de Brasil en perspectiva de un 'ideal universitario en América': otro legado de los estudiantes?", ponencia presentada en VII Jornadas de estudio y reflexión sobre el movimiento estudiantil argentino y latinoamericano, Facultad de Humanidades y Ciencias. Universidad Nacional del Litoral, Santa Fe, 31 de mayo y $1^{\circ}$ de junio de 2018.

${ }^{9}$ Luiz Antônio Cunha. A Universidade Temporã: o ensino superior, da Colônia à Era Vargas. São Paulo: Editora UNESP, 2007, $3^{\circ}$ ed., p. 189.
} 


\section{Fernando Romero Wimer - Paula Fernández Hellmund}

Praia Vermelha", cuando la Policía Militar reprimió en la madrugada a unos 600 estudiantes que ocupaban las instalaciones de la UFRJ. En 1968, el movimiento atravesó una ola ascendente de movilizaciones luego del asesinato del estudiante secundario Edson Luis de Lima Souto ${ }^{10}$ y la detención de numerosos estudiantes ${ }^{11}$ que se expresaron en varios hitos: "el viernes sangriento"12, "la marcha de los cien mil" en Rio de Janeiro ${ }^{13}$, "la batalla de la calle María Antonia" en São Paulo ${ }^{14}$ y la organización del XXX $X^{\circ}$ Congreso de la UNE convocado en Ibiúna (São Paulo). En este último acontecimiento fueron detenidos 800 estudiantes junto a los principales dirigentes: Vladimir Palmeiras, José Dirceu y Luís Travassos. ${ }^{15}$

Luego de años de represión y el exilio de los principales líderes, la UNE consiguió organizar el XXXI ${ }^{\circ}$ Congreso en Salvador (Estado de Bahia) a finales de mayo de 1979. ${ }^{16}$ En la década de 1980, la organización se involucró activamente en la democratización del país, reclamando la elección directa del presidente, bajo la consigna: "Diretas Já".

Ya en 1989, la dirección de la UNE confluyó con diferentes organizaciones populares -como la Central Única de Trabalhadores (CUT) y el Movimento de Trabalhadores Rurais Sem Terra (MST)- en la formación del Frente Brasil Popular y el lanzamiento de la campaña presidencial de Lula Da Silva.

En 1992, la UNE dio gran impulso a las manifestaciones contra el presidente Fernando Collor de Mello, mediante la campaña "Fuera Collor" y fue clave en la formación del movimiento de "Caras Pintadas", con que los jóvenes se identificaban pintando su rostro de verde y amarillo. ${ }^{17}$

\footnotetext{
${ }^{10}$ El 28 de marzo de 1968, el estudiante fue asesinado durante la invasión de la Policía Militar al predio del restaurante universitario "Calabouço" de Rio de Janeiro, durante las protestas por el precio de la comida. El hecho desencadenó protestas estudiantiles que fueron duramente reprimidas. El 4 de abril, al término de una misa en la Iglesia la Candelaria, en el centro de Rio de Janeiro, la caballería reprimió nuevamente a los asistentes.

${ }^{11}$ El 18 de junio de 1968, en Rio de Janeiro, es detenido el dirigente estudiantil Jean Marc von der Weid. Al día siguiente, al término de una asamblea, son detenidos 300 estudiantes.

${ }^{12}$ El 21 de junio de 1968 se registró la llamada "Sexta feira sangrenta". Ese día, una concentración estudiantil frente al edificio del periódico pro-dictadura "Jornal do Brasil" fue reprimida y 3 estudiantes resultaron muertos.

${ }^{13}$ La "Passeata dos Cem Mil" se realizó el 26 de junio de 1968 y convocó a distintos sectores de la sociedad brasileña, principalmente artistas, intelectuales y dirigentes políticos, a repudiar la represión y reclamar el fin de la dictadura.

${ }^{14}$ En octubre de 1968, en la "Batalha da Rua Maria Antonia" se enfrentaron estudiantes de derecha ligados al Comando Caça Comunistas (CCC) de la Universidade Mackenzie con jóvenes universitarios de izquierda vinculados a la UNE de la Universidade de São Paulo (USP). Las confrontaciones realizadas con armas de fuego, cohetes y molotov arrojaron un estudiante secundario muerto por un disparo y decenas de heridos.

${ }^{15}$ Jordana de Souza Santos, "A repressão ao movimento estudantil na ditadura militar". Revista Aurora, Marília, Vol. 3, $\mathrm{n}^{\circ}$ 1, 2009, pp. 101-108. Disponible en: http://www.bjis.unesp.br/ojs2.4.5/index.php/aurora/article/view/1224/1091 [Consulta: 30/04/2018].

${ }^{16}$ Luis Henrique Romagnoli y Tânia Gonçalves. A volta da UNE. De Ibiúna a Salvador. São Paulo, AlfaOmega, 1979.

17 Silene de Moraes Freire. "Movimento Estudantil no Brasil: lutas passadas, desafios presentes". Revista Historia de la Educación Latinoamericana, 2012, Nㅜ 11, pp. 131-146.
} 


\section{La União Nacional dos estudantes (UNE) ante el juzgamiento y la prisión de Lula da Silva}

\section{El proceso político nacional reciente}

El primer congreso del PT se realizó en marzo de 1980 congregando una militancia de izquierda de distintas vertientes y organizaciones, incluidos cuadros sindicales, militantes ligados a las Comunidades de Base y la Teología de la Liberación de la Iglesia Católica ${ }^{18}$, antiguos trotskistas y maoístas, y aquellos que rompieron con el Partido Comunista Brasileiro (PCB), el Partido Comunista do Brasil (PCdoB) y el Movimento Revolucionario 8 de Outubro (MR8), entre otros ${ }^{19}$. Desde entonces, el ascenso de la figura de Luiz Inácio Da Silva, "Lula" -un obrero metalúrgico de São Bernardo (São Paulo) que trascendió como líder de las mayores huelgas que enfrentó la última dictadura militar brasileña (1964-1985)- resultó un torbellino político que ocupó la segunda posición en tres elecciones presidenciales $(1989,1994$ y 1998) y, en 2002 y 2006, obtuvo los triunfos electorales que lo llevaron a la presidencia durante dos mandatos consecutivos (2003-2006 y 20072010).

Durante los gobiernos del PT, Brasil alcanzó la categoría de potencia global20, implantando una política neodesarrollista y de distribución del ingreso, y consiguiendo acumular un considerable nivel de reservas ${ }^{21}$. Brasil pasó de deudor internacional a miembro de los países acreedores del Fondo Monetario Internacional (FMI) y se tornó líder latinoamericano en propuestas de integración regional post-neoliberales o post-hegemónicas, como lo manifiestan el papel desempeñado en la creación de la Unión de Naciones Sudamericanas (UNASUR) y la Comunidad de Estados Latinoamericanos y Caribeños (CELAC).

En ese marco, el patrón exportador y extractivista de la economía brasileña se profundizó; el país exportó minerales y productos agropecuarios a niveles superlativos, mientras que el descubrimiento de petróleo "pre-sal" en el litoral atlántico brasileño prometía mayores niveles de prosperidad. ${ }^{22}$

Se produjo también durante el período una ampliación de la élite en el poder, en la cual se articuló el empresariado y la alta burocracia brasileña con dirigentes sindicales de la cúpula de la CUT. Algunos de estos últimos estuvieron vinculados a la administración de fondos de pensión, es decir una gestión que combina la militancia sindical y la gestión de inversiones financieras. ${ }^{23}$

\footnotetext{
18 Marta Harnecker. El sueño era posible. Los orígenes del Partido de los Trabajadores de Brasil narrados por sus protagonistas. La Habana, Cultura Popular, 1994, pp. 32-38.

19 Luis Bilbao. PT Brasil. Una respuesta latinoamericana al desafío imperialista. Buenos Aires, Búsqueda, 1990, p. 13.

20 Raúl Zibechi. Brasil potência. Entre a integração regional e o novo imperialismo. Rio de Janeiro, Consequência, 2012.

21 Paul Singer. "O processo econômico", en Daniel Reis (comp.). Modernização, ditadura e democracia: 1964-2010. Rio de Janeiro, Objetiva, 2014, p. 183-231.

22 Fabio Luís Barbosa dos Santos. Além do PT. A crise da esquerda brasileira em perspectiva latinoamericana. São Paulo, Elefante, 2016, p. 72.

${ }^{23}$ João Bernardo y Luciano Pereira. Capitalismo sindical. São Paulo, Xamã, 2008, pp. 13-14.
} 


\section{Fernando Romero Wimer - Paula Fernández Hellmund}

En diciembre de 2003, la disidencia de izquierda dentro del PT -compuesta por los diputados Heloísa Helena Lima de Moraes Carvalho, João Batista Araújo, Luciana Genro y João Fontes- fue expulsada de ese partido por oponerse a la reforma de las jubilaciones impulsada por el gobierno de Lula. Estos dirigentes fundaron al año siguiente el Partido Socialismo e Liberdade (PSOL). ${ }^{24}$

En 2005, los escándalos de corrupción de asociada al denominado "mensalão", involucró a José Dirceu ${ }^{25}$ : emblemático militante estudiantil en lucha contra la dictadura brasileña durante la década de $1960^{26}$, por entonces ministro de la Casa Civil -el ministerio más importante, dedicado a funciones de coordinación política de la presidencia-, y con fuertes posibilidades de suceder a Lula al frente de Brasil. El caso estuvo vinculado al pago de sobornos mensuales a diferentes diputados para que apoyaran proyectos de interés del Poder Ejecutivo. ${ }^{27}$

Los gobiernos de Lula realizaron una política social activa e impulsaron programas sociales -como "Bolsa Familia" y "Fome Zero"- que consiguieron disminuir la brecha de desigualdad social y la pobreza, ampliar la escolaridad y mejorar la salubridad de la población.

En el campo de la educación, durante la presidencia de Lula se crearon 11 (once) nuevas universidades federales a través del "Programa de Apoio aos Planos de Reestructuração e Expansão das Universidades Federais Brasileiras (REUNI)"28. Por medio del "Programa Universidade para todos (PROUNI)"29 se ampliaron las becas parciales o completas a jóvenes de bajos ingresos, negros e indígenas en

24 En 2006, Heloísa Helena fue candidata a presidente del Frente de Izquierda, compuesto por el PSOL, el PCB y el Partido Socialista dos Trabalhadores Unificado (PSTU). En 2010, el candidato del PSOL fue Plínio Arruda Sampaio y en 2014, la candidata a presidente fue Luciana Genro, quien había sido diputada federal por Rio Grande do Sul. En 2016, el PSOL se opusó al golpe conservador llevado adelante en el Congreso Nacional contra la presidenta Dilma Rousseff. En 2018, el PSOL -en alianza con el PCB- llevó como candidato a la presidente a Guilherme Boulos, integrante de la coordinación nacional del Movimento de Trabalhadores Sem Teto (MTST), el cual obtuvo el 0,6\% de los votos válidos en la elección del 7 de octubre de 2018. Desde 2010, el PSTU ha presentado candidaturas a la presidencia por separado. En 2018, Vera Lucia Pereira Da Silva Delgado -su candidata a la presidencia- obtuvo el $0,05 \%$ de los votos válidos.

25 En 1964, José Dirceu inició los estudios de abogacía en la Pontificia Universidade Católica (PUC) de São Paulo. En 1966, rompió con el PCB y se vinculó a la organización de la Dissidência de São Paulo (DI-SP). En 1967, fue presidente de la União Estadual de Estudantes (UEE) de São Paulo. En 1968, Dirceu fue arrestado y encarcelado por la dictadura militar. Fue liberado en 1969 junto a 14 presos y deportado a México, como intercambio por el embajador estadounidense Charles Burke Elbrick, secuestrado por el MR 8. Entre 1995 y 2002, Dirceu fue presidente nacional del PT. Véase, Jordana de Souza Santos. “A repressão ao movimiento estudantil...", op. cit.

${ }^{26}$ José Dirceu y Vladimir Palmeiras. Abaixo a ditadura. O movimento de 68 contado por seus líderes. São Paulo, Garamond, 1998.

27 Tomás Eon Barreiros y Danilo Amoroso. “Jornalismo estrábico: Veja e a Carta Capital na Cobertura do 'Escândalo do Mensalão'”. Perspectivas de la Comunicación. Temuco, Universidad de la Frontera, Vol. 1, No 1, pp. 120-131.

28 El REUNI fue creado mediante decreto presidencial $N^{\circ} 6.096$ en abril de 2007, cuyo objetivo principal era la ampliación del acceso y la permanencia de los estudiantes de graduación en el sistema de educación superior. La decisión determinó ocupaciones y protestas estudiantiles contra la adhesión de las universidades al programa y por preocupaciones en torno a la falta de presupuesto para hacer realidad ese objetivo.

${ }^{29}$ El PROUNI fue creado por la Ley 11.096 de enero de 2005 y está destinado a estudiantes de carrera de graduación de instituciones privadas. 


\section{La União Nacional dos estudantes (UNE) ante el juzgamiento y la prisión de Lula da Silva}

instituciones privadas. En julio de 2010, se estableció el Programa Nacional de Asistencia Estudiantil (PNAES) ${ }^{30}$, estableciendo como público beneficiario a los estudiantes de instituciones federales de educación superior provenientes del sistema público y con ingreso familiar per cápita de un salario mínimo y medio como máximo. ${ }^{31}$

Al final de su gobierno, Lula fue sucedido por Dilma Rousseff, quien fuera militante revolucionaria y guerrillera en la década de 1960, presa política durante los primeros años de la década de 1970, y ministra de Minas y Energía y, luego, de la Casa Civil durante la gestión del PT. Rousseff ganó las elecciones presidenciales de 2010 y obtuvo su primer mandato (2011-2014). En las elecciones de octubre de 2014 obtuvo su reelección.

Durante su gestión al frente del ejecutivo brasileño se crearon 7 (siete) universidades federales. En agosto de 2012, la presidente sancionó la Ley 12.711/12 -también llamada popularmente como "Lei de cotas"- que instituyó la reserva de vacantes en las universidades federales en proporción a la población negra e indígena de cada Estado de Brasil. ${ }^{32}$

En el plano de los derechos humanos, la Comisión Nacional de la Verdad ${ }^{33}$ fue instituida en noviembre de 2011 y puesta en funcionamiento en mayo de 2012. Esta comisión ha sido la encargada de investigar las violaciones a los derechos humanos ocurridos durante la última dictadura.

Las jornadas de junio de 2013 -movimiento multifacético que cuestionó el aumento del transporte público y, posteriormente, fue incorporando temas variados como la indignación contra la represión de la Policía Militar, el gasto público para los megaeventos deportivos (el Mundial de Fútbol de 2014 y los Juegos Olímpicos de 2016) y la corrupción política- fueron las mayores movilizaciones desde la época de las protestas contra el presidente Fernando Collor de Mello en 1992.34 La presidente Dilma Rousseff consideró, en ese contexto, que "la voz de la calle tiene que ser escuchada". 35

30 El PNAES fue instituido mediante el Decreto $\mathrm{N}^{\circ} 7.234$ de julio de 2010 y está destinado a estudiantes de bajos ingresos que cursen en instituciones federales. Tiene como principal objetivo contribuir con el desempeño académico y evitar que los estudiantes dejen los estudios. Dentro del programa existen acciones para vivienda estudiantil, transporte, alimentación, deporte, salud, guarderías, inclusión digital, cultura y apoyo pedagógico.

${ }^{31}$ Natalia Gomes dos Reis Dutra y Maria de Fátima de Souza Santos. "Assistência estudantil sob múltiplos olhares: a disputa de concepções". Ensaio. Avaliação e Politicas Públicas em Educação. Rio de Janeiro, Vol. 25, ํㅜ 94. Enero-marzo de 2017, pp. 148-181.

32 João Feres Junior, Verônica Toste Daflon y Luz Augusto Campos. "Ação afirmativa, raça e racismo: uma análise das ações de inclusão racial nos mandatos de Lula e Dilma". Revista de Ciências Humanas. Viçosa, Vol. 12, No 12, julio-diciembre de 2012, pp. 399-414.

33 Glenda Mezarobba. "Entre reparações, meias verdades e impunidade: o difícil rompimento com o legado da ditadura no Brasil”. Sur, São Paulo: Vol. 7, № 13, diciembre de 2010, pp. 7-25.

${ }^{34}$ Andrew Jennings, Raquel Rolnik y Antonio Lassance. Brasil em jogo. $O$ que fica da copa e das olimpíadas. São Paulo, Boitempo, 2014.

35 Dilma Rousseff, "Presidenta Dilma defende manifestações pacíficas 'A voz da rua tem que ser escutada". 18 de junio de 2013. Disponible en: https://www.youtube.com/watch?v=ENqoHRdV77E 


\title{
Fernando Romero Wimer - Paula Fernández Hellmund
}

Sin embargo, con el correr del tiempo, la dirigencia del PT reaccionó condenando las movilizaciones, incluso hasta la actualidad es interpretado como una reacción de derecha contra la democratización de Brasil. En agosto de 2017, Lula afirmó que las jornadas de junio de 2013 fueron promovidas por la Rede Globo -principal grupo de medios de comunicación del país- y los intereses de la elite brasileña: "Nós nos precipitamos ao achar que 2013 foi uma coisa democrática. Que o povo foi para a rua porque estava muito preocupado com aquela coisa do transporte coletivo".36

También fueron interpretadas como el inicio de las protestas que pusieron fin al gobierno de Dilma Rousseff, un movimiento que sirvió de formato de expresión a la derecha. ${ }^{37}$ Fernando Haddad, ex ministro de Educación de Lula y Rousseff y, por entonces, jefe de gobierno de la ciudad de São Paulo expresó en 2017:

\begin{abstract}
"Muito bem, o povo foi para rua para protestar contra a tarifa. Mas o que houve de fato de mais importante não foi isso. 0 que houve de fato mais importante foi o sequestro pela direita da forma de organização de aquele movimento original. Na verdade, minha tese é que a direita estava com muita dificuldade de se exprimir politicamente. Não estava conseguindo encontrar canais de expressão de seus desejos, de suas vontades, de suas angústias, de esse ressentimento. (...) 2013 deu a chave do ponto de vista da forma. (...) Portanto, o conteúdo do protesto contra a tarifa e o menos importante ali." 38
\end{abstract}

No obstante, si bien es cierto que la participación antigubernamental se expresó en aquel momento y constituyó un antecedente de las concentraciones de 2015 y 2016, el grueso de los manifestantes lo constituyeron jóvenes insatisfechos con el escenario político y social. En particular, se trataba de jóvenes trabajadores estudiantes o estudiantes trabajadores; un segmento social que se reconfiguró en torno al crecimiento económico, dado que aproximadamente el $60 \%$ de los empleos creados durante los últimos años fueron ocupados por jóvenes entre 18 y 24 años. Éstos, además, fueron quienes accedieron a las universidades en el contexto de la expansión de la enseñanza superior en el país. ${ }^{39}$

En 2014, los reclamos políticos del año anterior fueron relativamente recuperados por los principales candidatos en la campaña electoral. Rousseff evaluó

\footnotetext{
36 Folha de São Paulo, "Lula diz que foi precipitado considerar atos de 2013 democráticos". Folha de São Paulo. São Paulo, 11 de agosto de 2017. Disponível em: https://www1.folha.uol.com.br/poder/2017/08/1909354-lula-diz-que-foi-precipitadoconsiderar-atos-de-2013-democraticos.shtm [Consulta: 20/09/2018]

37 Posteriormente, algunas organizaciones políticas de la derecha que consiguieron masificar las acciones de protestas en las redes sociales y en las calles. Un ejemplo de ello es la creación del Movimento Brasil Livre (MBL), una organización liberal fundada en 2014.

38 Fernando Haddad, "Ruas rebeldes I Fernando Haddad: a catarse e a ressaca política", 23 de julio de 2017, em: https://www.youtube.com/watch?v=3qXnX2nglY0 [Consulta: 03/10/2018]

${ }^{39}$ Ruy Braga. "Precariado e sindicalismo no Brasil contemporâneo: um olhar a partir da indústria do call center". Revista Crítica de Ciencias Sociales, Coimbra, 2014, N103, pp. 25-52.
} 


\section{La União Nacional dos estudantes (UNE) ante el juzgamiento y la prisión de Lula da Silva}

que los jóvenes expresaban la voluntad de cambio de Brasil y que era su obligación oír las manifestaciones y dialogar con todos los segmentos. ${ }^{40}$ Pero esos posicionamientos no se tradujeron luego en su agenda del gobierno. Ese mismo año, el pago de intereses y amortizaciones de la deuda pública representaba un $45 \%$ de todo el presupuesto federal ejecutado. ${ }^{41}$

La estrecha victoria de Rousseff sobre Aecio Neves en los comicios presidenciales y la reversión de los precios internacionales de los commodities marcaron el camino para un cambio hacia una política de derecha. En la composición del nuevo gabinete de gobierno -iniciado en 2015- se destacó la presencia de: Katia Abreu, como ministra en Agricultura, procedente de la bancada ruralista y que sostenía la inexistencia del latifundio en Brasil; un banquero, Joaquim Levy, como ministro de Hacienda; un dirigente industrial, Armando Monteiro, como ministro de Desarrollo Industrial y Comercio; un pastor de la Iglesia Universal, George Hilton, como ministro de Deportes, y otros de un perfil conservador. Apenas iniciada la nueva gestión fue anunciado un ajuste fiscal.

Sin embargo, para los intereses del gran capital y las clases dominantes brasileñas el giro conservador del gobierno de Dilma Rousseff no fue suficiente. Para debilitar el gobierno electo se promovieron cada vez con mayor fuerza las manifestaciones a favor del juicio político a la presidente, simultáneamente se expresaron en los medios de comunicación posiciones a favor de acortar el mandato. Las acusaciones de corrupción en el seno del propio PT -como las que implicaban al propio Lula en el caso Petrobras (conocido por operación "Lava Jato") y a Dilma en torno al maquillaje de las cuentas públicas- desencadenaron grandes escándalos. El proceso de denuncia contra la presidente Dilma Rousseff fue aprobado por la Cámara de Diputados el 2 de diciembre de 2015, dando inicio también a la ruptura del Partido Movimiento Democrático Brasileiro (PMDB) del vicepresidente Michel Temer con el PT.

Durante el año 2016, el gobierno anunció la puesta en ejecución de más puntos programáticos de la derecha: una reforma de las jubilaciones y una reforma fiscal. Además, en febrero, Rousseff aceptó sin oponerse la aprobación del proyecto de ley que abría oportunidades de nuevas concesiones al capital extranjero en torno a la explotación del petróleo del pre-sal. De este modo, previo al golpe parlamentario, la militancia del PT y la izquierda -movilizada en niveles inferiores a los manifestantes pro-impechmeant- recibió con resignación una nueva concesión del gobierno a la derecha. ${ }^{42}$

\footnotetext{
${ }^{40}$ Fernando Emmendoerfer de Castro. "As manifestações brasileiras de 2013 sob a ótica do HGPE dos candidatos a presidente do Brasil em 2014", Curitiba, UFPR, 2016 (Tesis de Maestría); Carla Montuori Fernandes, Talita Lucarelli Moreira y Thamiris Franco Martins "Ativismo, comunicação e política: a voz das ruas em 2013 e o discurso político no HGPE em 2014". IX Simpósio Nacional ABCiber, PUC, 2016.

41 Fabio Luís Barbosa dos Santos. Além do PT...op. cit. p. 94.

42 Previamente, las organizaciones populares y de izquierda se habían manifestado públicamente contra el ajuste. El 3 de octubre de 2015, el Frente Brasil Popular organizó su primera gran manifestación pública contra las concesiones del petróleo pre-sal, por los derechos sociales y la
} 
El 4 de marzo de 2016, el caso de Petrobras llevó a la primera detención de Lula Da Silva para ser indagado por corrupción. Posteriormente, el 16 de marzo de 2016, fue nombrado por la presidente Rousseff como ministro de la Casa Civil, pero su asunción al cargo fue judicialmente bloqueada por el Supremo Tribunal Federal (STF).

A fines de marzo, los ministros del PMDB renunciaron, consumando la ruptura con la presidente. En abril y mayo, las Cámaras de Diputados y de Senadores aprobaron el juicio político, apartando a Rousseff de su cargo de presidente por 180 días para ser juzgada. Finalmente, el 31 de agosto fue destituida definitivamente por el Senado. ${ }^{43}$

En julio de 2017, Lula Da Silva fue condenado en primera instancia por el juez Sergio Moro a 9 años y 6 meses de prisión. En enero de 2018, es nuevamente condenado en segunda instancia y su condena aumentaba a 12 años. ${ }^{44}$

En abril de 2018 se produjo la negativa del STF al recurso de Habeas Corpus presentado por Lula para no ir a la cárcel. En la víspera de ese juzgamiento, el comandante en jefe del Ejército, general Eduardo Villas Boas, sostuvo en Twitter que el Ejército brasileño, repudiaba la impunidad y compartía con todos los ciudadanos el anhelo de respeto a la Constitución. ${ }^{45}$ El encarcelamiento del líder del PT se produjo en momentos que encabezaba las encuestas como candidato a presidente para las elecciones de este año.

\section{La composición social del estudiantado universitario}

Para el conjunto de la juventud brasileña fue crucial la recuperación del valor del salario durante los gobiernos del PT aumentando de 2003 a 2014 un 76,5\%, aunque la tendencia ya había iniciado en las presidencias de Fernando Henrique Cardoso (1994-2002) con una recuperación del 42\%. Por esto, tuvo mayor

\footnotetext{
democracia. El MST denunció los intereses del gran capital y las potencias imperialistas em las disputas en torno al petróleo brasileño. Véase Noria Segatto, "Frente Brasil Popular, a defesa de Petrobrás e os interesses internacionais em disputa", Movimento dos Trabalhadores Rurais Sem Terra (MST), 30 de septiembre de 2015. Disponible en: http://www.mst.org.br/2015/09/30/frentebrasil-popular-a-defesa-da-petrobras-e-os-interesses-internacionais-em-disputa.html [Consulta: 20/09/2018].

${ }^{43}$ A medida que fue avanzando el propio proceso de destitución, los manifestantes contra el golpe parlamentario a Dilma Rousseff fueron disminuyendo, evidenciando un proceso de frustración frente a las decisiones tomadas por las principales instituciones políticas del país. TL13, "TL13 en Brasil: Así se vivió la destitución de Dilma Rousseff", 31 de agosto de 2016. Disponible en: http://www.t13.cl/videos/mundo/t13-brasil-asi-se-vivio-destitucion-dilma-rousseff [Consulta: 03/09/2018].

${ }^{44}$ La acusación que lo llevó a la prisión de Lula es por corrupción pasiva y lavado de dinero, asociado a una vivienda de tres pisos en Guarujá (São Paulo) que el ex presidente recibiera por favores concedidos a la constructora OAS en los contratos con Petrobras.

${ }^{45}$ Rubens Valente, Talita Fernandes y Anna Virginia Ballousier. "Na véspera do julgamento a Lula, comandante do Exército diz repudiar a impunidade". Folha de São Paulo, São Paulo, 3 de abril de 2014. Disponible en: https://www1.folha.uol.com.br/poder/2018/04/na-vespera-de-julgamentosobre-lula-comandante-do-exercito-diz-repudiar-impunidade.shtml [Consulta: 30/04/2018].
} 


\section{La União Nacional dos estudantes (UNE) ante el juzgamiento y la prisión de Lula da Silva}

incidencia la ampliación del empleo durante los gobiernos de Lula Da Silva y Dilma Rousseff, luego del desempleo de masas de la década de 1990.

De igual modo, vale prestar atención a cómo avanzó la participación del trabajo en el ingreso nacional entre 2002 y 2009 de 42,4\% a 43,6\%. Sin embargo, todavía este resultado era inferior a 1994, cuando la participación del trabajo alcanzó 48\% e inferior a los años 1959-1960, cuando llegó al 57\%46.

Asimismo, en términos cualitativos, se observaron retrocesos en las relaciones de trabajo. La tercerización de las empresas, la flexibilidad de la jornada de trabajo, las distintas formas de informalidad, y los accidentes y muertes durante la jornada laboral pasaron a incrementarse a la par que se expandían los agronegocios, la construcción civil y el sector servicios.

Muchos de los jóvenes que durante los gobiernos del PT tuvieron su primer empleo -en muchos casos, en diferentes condiciones de trabajo precario- pasaron a cursar en las universidades con la expectativa de mejorar su condición laboral y de vida. Si bien es cierto que los gobiernos petistas crearon 18 nuevas universidades federales y expandieron el ingreso a través del REUNI, el PROUNI y el Fundo de Financiamento Estudantil (FIES) ${ }^{47}$, el sector privado resultó el más beneficiado. ${ }^{48}$

Así, el Estado subsidió con estos programas el negocio de la educación superior privada. ${ }^{49}$ Según el Censo de Educación Superior de 2016: de un total de 8 millones de estudiantes, unos 6 millones cursaban en instituciones privadas; y de 2.407 instituciones de enseñanza superior, 2.111 eran privadas. ${ }^{50}$ Vale mencionar que esta situación consolidó en Brasil a las grandes empresas de educación, como Pearson (de capital inglés), Anima Educação, Ser educacional, Abril Educação, DeVry Brasil (de capital estadounidense), Universidade Paulista (que forma parte del grupo Objetivo), Uninove, Cruzeiro do Sul Educacional, Laureate, Unicesumar y Estácio Participações. ${ }^{51}$ En 2013, la fusión de grupos dio lugar a la formación de la mayor empresa de educación de Brasil y una de las mayores del mundo en ese rubro: la corporación Kroton-Anhanguera. ${ }^{52}$

\footnotetext{
${ }^{46}$ Fabio Luís Barbosa dos Santos. Além do PT ..., op. cit., pp. 75-77.

${ }^{47}$ Es un fondo público creado en 1999 por el Ministerio de Educación de Brasil durante el gobierno de Fernando Henrique Cardoso y ampliado durante el gobierno de Lula Da Silva. El fondo está destinado al financiamiento de los aranceles mensuales de los estudiantes matriculados en carreras presenciales y no gratuitas que cuenten además con una evaluación positiva del Ministerio.

${ }^{48}$ Vera Lucia Jacob Chaves y Nelson Cardoso Amaral. "Politica de Expansão da Educação Superior no Brasil: o PROUNI e o FIES como financiadores do setor privado". Educação em Revista. Belo Horizonte, Vol. 32, $\mathrm{N}^{\circ}$ 4, octubre-diciembre de 2016. pp. 42-72.

${ }^{49}$ Allan Kenji Seki y Olinda Evangelista. "Reforma Universitária no governo Lula. 0 que queriam os industriais". Trabalho necessário. Rio de Janeiro, UFF, № 23, 2016, pp. 67-93.

50 REPÚBLICA FEDERAL DO BRASIL. MINISTERIO DE EDUCACIÓN (MEC). Censo de Educação Superior 2016. Principais resultados. Brasilia: MEC-INEP, 2017. Disponible en: http://download.inep.gov.br/educacao_superior/censo superior/documentos/2016/censo superi or tabelas.pdf [Consulta: 30/04/2018].

${ }^{51}$ Fábio Luciano Oliveira Costa. Financeirização do Capital no Ensino Superior Privado com fins lucrativos no Brasil (2007-2012). Tesis de doctorado. Programa de Posgrado en Educación. Universidade de São Paulo, 2016.

${ }^{52}$ KROTON EDUCACIONAL S.A. "Histórico". Disponible en: http://www.kroton.com.br/ [Consulta: 12 de junio de 2018].
} 


\section{Fernando Romero Wimer - Paula Fernández Hellmund}

De esta manera, es oportuno considerar que los estudiantes trabajadores o los jóvenes trabajadores que estudian consiguieron entrar a la educación superior pero también convertirse en potenciales clientes de las instituciones privadas. ${ }^{53} \mathrm{En}$ 2014, casi 2 millones de estudiantes eran beneficiados por el FIES, lo cual representaba un tercio de los inscriptos en el sector privado ${ }^{54}$.

En cuanto a la participación de estudiantes de bajos ingresos, negros e indígenas en las universidades públicas, los guarismos oficiales constataron que, entre 2004 y 2011, se produjo un incremento de aumento de estudiantes del quintil de menores ingresos del 0,6 a 4,2\%, los negros pasaron del 5\% al 8,8\%, y los pardos del 5,6\% al 11\%55. No obstante, la participación sigue siendo baja si se considera el porcentual de esos sectores sociales en el total del país, situación asociada a la desigualdad social, la postergación histórica y la discriminación racial que sufrida en Brasil. ${ }^{56}$

En el plano de las organizaciones, como ya mencionáramos, la principal entidad de alcance en todo el país es la União Nacional dos Estudantes (UNE), creada en 1937. La UNE nuclea unas 30 corrientes estudiantiles y es dirigida por la União da Juventude Socialista (UJS), ligada al PCdoB (aliado al PT). Cada dos años la UNE convoca un Congreso Nacional -CONUNE- que reúne miles de estudiantes de todo Brasil.

En un nivel minoritario, se constituyó en 2004 la Coordenação Nacional de Luta dos Estudantes (CONLUTES), transformada en 2009 en la Assambleia Nacional dos Estudantes-Livre (ANEL), impulsada por el PSTU. Esta última organización creada en 1994 por disidentes trotskistas del PT- no apoya la liberación de Lula y no considera que la justicia haya sido selectiva a la hora de juzgar al ex presidente por corrupción. ${ }^{57}$

A nivel de base, los estudiantes se agrupan por Centros Académicos que representan a todos los estudiantes de una carrera. También existen los Directorios Académicos, que organizan a estudiantes de más de una carrera, y el Directorio Central de los Estudiantes (DCE), que se constituye como una organización general de los estudiantes de una universidad. Asimismo, la União Estadual dos Estudantes (UEE) representa a los estudiantes de cada Estado federal de Brasil.

\section{Lucha estudiantil frente al juzgamiento y prisión de Lula}

\footnotetext{
53 Roberto Leher. "Educación pública, movimientos sociales y recuperación de la educación en Brasil". Intercambio. Red Sobre Educación Pública en las Américas (SEPA), Año 6, N 7, abril de 2015, p. 14-16. Disponible en: http://revistaintercambio.org/index.php/INTERCAMBIO/article/view/5 [Consulta: 29/04/2018].

54 Fabio Luís Barbosa dos Santos. Além do PT..., op. cit., p. 79.

55 REPÚBLICA FEDERAL DO BRASIL. MINISTERIO DE EDUCACIÓN (MEC). Censo de Educação Superior 2011. Brasilia: MEC-INEP, 2012.

56 Dilvo Ristoff. "O novo perfil do campus brasileiro: uma analise do perfil socioeconómico do estudante de graduação". Avaliação: Revista de Avaliação da Educação Superior. Sorocava, Vol. 19, № 3, 2014, pp. 723-747.

57 PARTIDO SOCIALISTA DOS TRABALHADORES UNIFICADO (PSTU). "STF nega habeas corpus e prisão de Lula é decretada". 5 de abril de 2018. Disponible en: https://www.pstu.org.br/stf-negahabeas-corpus-e-prisao-de-lula-e-decretada/ [Consulta: 23/04/2018].
} 


\section{La União Nacional dos estudantes (UNE) ante el juzgamiento y la prisión de Lula da Silva}

En 2011, durante el $52^{\circ}$ CONUNE contó con la presencia del ex presidente Lula, un hecho que tiene como antecedentes la participación en los Congresos de 1980 -cuando todavía era sindicalista- y 2009, ya como presidente de Brasil. La participación de Lula -junto con el ministro de Educación Fernando Haddad (20052012)- se realizó en el marco del $I^{\circ}$ Encuentro Nacional de Estudiantes del PROUNI, actividad integrada al $52^{\circ}$ Congreso. La relación de la dirección de la UNE con los gobiernos del PT fue estrecha, más allá del lanzamiento de campañas que demandaron aumento del presupuesto y mejoras en la educación (como las asociadas a las campañas "A educação não é mercadoria" y "Quem entrou, quer ficar") ${ }^{58}$.

El lema del $54^{\circ}$ CONUNE -convocado en la ciudad de Goiânia, en junio de 2015- fue "Defensa de la Democracia, de los Estudiantes y de Brasil", en un evento marcado ya por la ola conservadora y el ajuste. Por entonces, en los primeros meses del segundo mandato de Rousseff, los principales temas que convocaban a la lucha estudiantil eran: la reducción de la mayoría penal para los 16 años, el recorte de $\mathrm{R} \$$ 9.000 millones para la Educación, y la ampliación de la tercerización de los trabajadores.

En diciembre de 2015, la UNE se posicionó en contra del impeachment de la presidente y convocó a todos los movimientos sociales a ganar las calles para defender la democracia. ${ }^{59}$

En febrero de 2016, la UNE denunció la ley que excluía a la Petrobras como operadora única del presal, abría la participación de empresas multinacionales e impactaba en la reducción del presupuesto para educación. Sin embargo, no consiguió convocar a una movilización por aquellos días y la ley fue aprobada de urgencia. 60

El 4 de marzo de 2016, la UNE se posicionó contra la detención de Lula y su traslado coercitivo para declarar en la Operación "Lava Jato", acusando de selectividad a la Policía Federal y recolocando el debate sobre la defensa del Estado democrático de derecho. ${ }^{61}$ La detención espectacular del ex presidente involucró

\footnotetext{
${ }^{58}$ En 2014, la UNE inició la campaña "la educación no es mercadería", denunciando a los empresarios de la educación -llamados "tiburones de la enseñanza"- que aumentan los aranceles mensuales de las universidades privadas y, en ocasiones, no realizan las inversiones requeridas en la infraestructura. La campaña se reeditó nuevamente en los primeros meses de 2018. En 2015, la UNE demandó el aumento del presupuesto para el PNAES, mediante la campaña "Quem entrou, quer ficar".

${ }^{59}$ UNIÃO NACIONAL DOS ESTUDANTES (UNE), "UNE se posiciona contra impeachment de Dilma Rousseff", 5 de diciembre de 2015. Disponible en: http://www.une.org.br/noticias/une-seposiciona-contra-impeachment-de-dilma-rousseff/ [Consulta: 17/10/2018].

60 UNIÃO NACIONAL DOS ESTUDANTES (UNE), "Estudantes contra nova partilha do pré-sal", 24 de febrero de 2016. Disponible en: http://www.une.org.br/noticias/estudantes-contra-a-novapartilha-do-pre-sal/ [Consulta: 17/10/2018]. Ver vídeo UNIÃO NACIONAL DOS ESTUDANTES (UNE). "O pré-sal é do Brasil", 16 de marzo de 2016. Disponible en: http://www.une.org.br/tv-une/o-presal-e-do-brasil/ [Consulta: 17/10/2018].

${ }^{61}$ UNIÃO NACIONAL DOS ESTUDANTES (UNE). "Nota da UNE sobre condução coercitiva de Lula para depoimento da Policia Federal". 4 de marzo de 2016. Disponible en:
} 


\section{Fernando Romero Wimer - Paula Fernández Hellmund}

unos 200 agentes y fue seguida en directo por los grandes medios de comunicación, especialmente por el poderoso Grupo Globo.

En mayo de 2016, frente a la aprobación del juicio político a la presidente Rousseff por parte del Senado Federal, la UNE declaró que Brasil no volvería a repetir un golpe de Estado como en 1964. ${ }^{62}$ Por entonces, Carina Vitral -presidente de la UNE- manifestó que, si Rousseff no recuperase el gobierno luego del juicio político, la UNE presionaría para un nuevo llamado a elecciones bajo la consigna "Fuera Temer".63

En noviembre de 2016, las movilizaciones estudiantiles sostuvieron la ocupación de más de 170 campus de Universidades en todo Brasil frente a la Propuesta de Enmienda de la Constitución (PEC) N 55 -llamada PEC del "techo del gasto público"-, propuesta por el gobierno de Michel Temer.

En junio de 2017, la nueva presidente de la UNE, Marianna Dias, afirmó que: "nós vamos a derrotar o presidente golpista da República e construir uma grande jornada de luta, uma grande greve geral"64. Es de notar la distancia entre este deseo político y la realidad de las organizaciones: ni durante el impeachment a Dilma Rousseff ni frente a la detención y juzgamiento de Lula fue convocada una huelga general, ni por la dirección estudiantil ni por las centrales de trabajadores.

El 20 de julio de 2017, la UNE se movilizó junto a los partidos políticos de izquierda aliados al gobierno, los movimientos sociales -entre los que se destacó la movilización del MST- y organizaciones sindicales -como la CUT-, en defensa y solidaridad del ex presidente Lula frente a la condena del juez Moro. Marianna Dias fue parte de quienes dirigieron un discurso a quienes se concentraron frente al Museo de Arte de São Paulo (MASP). Ese mismo día, quienes estaban a favor de la prisión del ex primer mandatario se concentraron en la Federación de Industrias del Estado de São Paulo (FIESP).

En agosto de 2017, la UEE São Paulo -federada a la UNE- fue protagonista de la ocupación de la Cámara Municipal de São Paulo. La medida fue realizada en contra de los recortes al "pase libre" estudiantil y los proyectos privatizadores impulsados en la ciudad. 65

http://www.une.org.br/noticias/nota-da-une-sobre-conducao-coercitiva-de-lula-paradepoimento-da-pf/ [Consulta: 30/04/2018].

62 UNIÃO NACIONAL DOS ESTUDANTES (UNE). "O Brasil não anoitecerá: nota da UNE sobre afastamento de Dilma Rousseff". 12 de mayo de 2016. Disponible en: http://www.une.org.br/noticias/o-brasil-nao-anoitecera-nota-da-une-sobre-afastamento-dedilma-rousseff/ [Consulta: 30/04/2018].

63 Marcela Fernandes. "UNE admite que Dilma pode não voltar e discute novas eleições, diz presidente da entidade", em: Huffpost, 19 de mayo de 2016. Disponible en: https://www.huffpostbrasil.com/2016/05/19/une-admite-que-dilma-pode-nao-voltar-e-discutenovas-eleicoes-d a 21682553/ [Consulta: 30/05/2016].

${ }^{64}$ UNIÃO DA JUVENTUDE SOCIALISTA (UJS). "Marianna Dias: 'A UNE uma grande história de amor ao Brasil'”. 19 de junio de 2017. Disponible en: http://ujs.org.br/index.php/noticias/marianna-diasa-une-e-uma-grande-prova-de-amor-ao-brasil// [Consulta: 23/04/2018].

${ }^{65}$ Sara Puerta. "Estudantes e movimentos sociais ocupam a câmara de SP há mais de 24 horas", en: UNIÃO NACIONAL DOS ESTUDANTES (UNE), 10 de agosto de 2017. Disponible en: http://www.une.org.br/noticias/estudantes-e-movimentos-sociais-ocupam-a-camara-de-sp-hamais-de-24-horas/ [Consulta: 23/04/2018]. 


\section{La União Nacional dos estudantes (UNE) ante el juzgamiento y la prisión de Lula da Silva}

En enero de 2018, durante la semana de juzgamiento por el Tribunal Regional Federal (TRF 4) en Porto Alegre, el Frente Brasil Popular y el Frente Povo Sem Medo -dos organizaciones que nuclean movimientos sociales y organizaciones sindicales- convocaron a diversos actos en defensa de la democracia y el derecho de Lula de ser candidato. La UNE integra esos frentes junto al MST, la CUT, la Central dos Trabalhadores Brasileiros (CTB) y Movimento dos Trabalhadores Sem Teto (MTST). ${ }^{66}$

El 6 de abril de 2018, la UNE se movilizó hacia São Bernardo do Campo, sede del Sindicato de los Metalúrgicos del ABC paulista, desde donde Lula Da Silva se dirigió a la multitud convocada ante su inminente encarcelamiento. Marianna Dias afirmó que la prisión de Lula implicaba una grave amenaza para la democracia brasileña y manifestó la convicción de que el expresidente debía estar libre y ser candidato a la presidencia de la República. ${ }^{67}$

El sábado 7 de abril de 2018, en horas de la tarde, Lula se presentó a la Policía Federal y fue trasladado para su prisión en Curitiba. Desde entonces, la dirección de la UNE y su militancia se ha congregado frente a la sede de la Policía Federal en Curitiba en el campamento "Lula livre". El día 11 de abril, la organización también fue parte de la movilización nacional en defensa de la libertad del dirigente del PT. ${ }^{68}$ Asimismo, esa noche, la dirección de la UNE acordó con la dirección de la União Brasileira dos Estudantes Secundaristas (UBES) la creación de Comités de Defensa de la Democracia y de la libertad de Lula, y convocaron un día de lucha en Curitiba para el 17 de abril. Ese día también se realizó el lanzamiento de la "UNE volante", una caravana de presentaciones y conferencias en diferentes universidades del país. ${ }^{69}$

En agosto de 2018, Marianna Dias expresó públicamente el apoyo de la UNE a Lula como candidato a presidente, "por todo lo que sus ideas representan".70 Posteriormente, cuando la candidatura del ex presidente fue rechazada, la UNE junto con la UBES y la Asociação Nacional de Pós-Graduandos (ANPG)- pasó a apoyar la fórmula presidencial de Fernando Haddad (PT) junto a Manuela D’Ávila (PCdo B)

\footnotetext{
66 UNIÃO NACIONAL DOS ESTUDANTES (UNE). "SP: Ato em defesa da democracia e de Lula acontece na Praça da República". 23 de enero de 2018. Disponible en: http://www.une.org.br/noticias/sp-atoem-defesa-da-democracia-e-de-lula-acontece-na-praca-da-republica/ [Consulta: 05/05/2018]. 67 TV247, "Marianna Dias, da UNE: se Lula for preso, será presa a democracia", 6 de abril de 2018. Disponible en: https://www.youtube.com/watch?v=5TeT6VB4Kvs [Consulta: 15/10/2018].

${ }^{68}$ UNIÃO NACIONAL DOS ESTUDANTES (UNE). "Dia de Mobilização em defesa da liberdade de Lula acontece nesta quarta 11". 10 de abril de 2018. Disponible en: http://www.une.org.br/noticias/diade-mobilizacao-em-defesa-da-liberdade-de-lula-acontece-nesta-quarta-11/ [Consulta: 11/04/2018].

${ }^{69}$ UNIÃO NACIONAL DOS ESTUDANTES (UNE). “UNE e UBES propõem a criação de comitês em defesa da democracia e de Lula". 12 de abril de 2018. Disponible en: http://www.une.org.br/noticias/unee-ubes-propoe-a-criacao-de-comites-em-defesa-da-democracia-e-de-lula/ [Consulta: 20/04/2018]. ${ }^{70}$ PARTIDO DOS TRABALHADORES (PT), "Assista: presidenta da UNE defende a candidatura de Lula", 4 de agosto de 2018. Disponible en: http://www.pt.org.br/assista-presidenta-da-une-defende-acandidatura-de-lula/ [Consulta: 17/10/2018].
} 


\section{Fernando Romero Wimer - Paula Fernández Hellmund}

como vicepresidente. También firmó una carta "contra el odio y en defensa de la democracia" contra el candidato Jair Bolsonaro del Partido Social Liberal (PSL). ${ }^{71}$

Con todo, vale decir que los cuestionamientos y la representatividad de la UNE están a la orden del día. La dirección de la UNE enfrenta tanto la crítica por izquierda (por la afinidad con las políticas del PT), como por derecha (por el gasto público de las universidades, sus alianzas con movimientos y organizaciones de izquierda y su apoyo a la política social y de expansión de la educación). A estas dificultades se agrega el relativo distanciamiento de los diferentes niveles de cuadros de dirección con la mayoría del estudiantado y el alejamiento de las pautas clasistas (que sólo parcialmente equilibró incorporando en sus luchas cuestiones étnicas y de género -feministas y transgéneros-) que, en ocasiones, encuentran como respuesta la pérdida de masividad de las convocatorias, colocan en un nivel secundario los problemas políticos más amplios y atomizan las luchas estudiantiles. ${ }^{72}$ Tampoco otros conflictos en torno a la democratización interna de las universidades, los reclamos por disminución del precio del transporte, el acceso a comedores universitarios y la distribución de las becas han servido para movilizar a favor de cuestiones políticas de mayor amplitud.

Entonces, cuando se agudiza el seguimiento judicial contra los líderes del PT -Lula Da Silva y Dilma Rousseff-, el movimiento estudiantil universitario está sumergido en la misma dispersión y resignación del conjunto de la izquierda brasileña, no consiguiendo constituirse en un sujeto que tensione y cuestione el escenario político, así como no se constituye en una referencia de movilizaciones masivas en todo el país. ${ }^{73}$ El crecimiento electoral de la extrema derecha y el avance del conservadurismo en la opinión pública resultan la otra cara de la moneda. ${ }^{74}$

\section{Síntesis y conclusiones}

El proceso político en el que desemboca el juzgamiento y prisión de Lula está atravesado por el ascenso, auge y declive del PT. Constituido como una fuerza política alternativa y unitaria que agrupó a distintas tendencias de la izquierda brasileña, el PT llegó a la presidencia en 2003. Sin embargo, desde los gobiernos petistas -sin desmedro de reconocer los avances relativos de su política social- no se aprovechó la correlación de fuerzas favorable para transformar el Estado brasileño. Por el contrario, se impulsaron medidas que pactaron con el gran capital y la cúpula

\footnotetext{
${ }^{71}$ Renata Bars. "UNE, UBES e ANPG assinaram carta contra o ódio e saem em defesa da democracia". UNIÃO NACIONAL DOS ESTUDANTES (UNE), 15 de octubre de 2018 http://www.une.org.br/noticias/une-ubes-e-anpg-assinam-carta-contra-o-odio-e-saem-em-defesada-democracia/ [Consulta: 17/10/2018].

72 María Victoria Espiñeira y Cláudio André de Souza. "Mobilizações dentro e fora das ruas: uma análise dos ciclos de protesto do movimento estudantil brasileiro nas últimas três décadas", ponencia presentada en el $18^{\circ}$ Congresso Brasileiro de Sociologia. Brasilia, 26 a 29 de julio de 2017.

73 Véase una perspectiva similar en la nota reciente de Julio Fisherman, "La ofensiva golpista y la tímida respuesta de los movimientos populares en Brasil", Iberoamérica Social. Revista-Red de Estudios Sociales, Sevilla, Año 5, $\mathrm{N}^{\circ}$ X, junio de 2018, pp. 32-34.

${ }^{74}$ Una dura crítica a las concesiones del PT al gran capital que alarma -con suficiente antecedenciasobre las posibilidades de ascenso del fascismo fue realizada por el profesor Salles. Véase, Severo Salles. La lucha de clases en Brasil (1960-2012). Buenos Aires, Continente, 2013, pp. 137-142.
} 


\section{La União Nacional dos estudantes (UNE) ante el juzgamiento y la prisión de Lula da Silva}

empresarial. Al mismo tiempo, se incentivaron las prácticas de venalidad y pragmatismo características de la política profesional convencional. Al abdicar de su programa, el PT también se encaminó para mantener incólume la dominación de clase del Estado y preparar el escenario de su propio tormento. Del lado de los sectores más combativos y organizados de los movimientos sociales, el alineamiento con el gobierno y la cooptación terminaron neutralizando y despolitizando las bases populares que llevaron al triunfo electoral de 2002.

La composición social del estudiantado se modificó parcialmente. Los pobres, negros e indígenas incrementaron su participación en las universidades, pero aún son una minoría dentro de ellas. El perfil del estudiantado pasó a definirse principalmente por estudiantes que pagan las universidades privadas con o sin beca y los estudiantes de graduación que asisten a la universidad pública y gratuita con o sin beca. Varios de los programas impulsados por el gobierno sirvieron a la expansión universitaria; de todos modos, el principal beneficiario fue el negocio de la educación privada. Nunca se discutió el ingreso irrestricto a las universidades; por lo tanto, la característica principal de las universidades brasileñas es la entrada restringida a través de vacantes.

El nivel de participación e involucramiento del estudiantado en las organizaciones y movilizaciones estudiantiles se ha debatido entre la desilusión y la fragmentación. Profundizado el accionar judicial contra Lula, la UNE articuló diferentes formas de lucha con sindicatos y centrales de trabajadores, y movimientos sociales de las ciudades y del campo. La principal organización estudiantil llamó a los estudiantes a concentraciones en defensa de la democracia, contra la persecución judicial y, luego, la detención arbitraria del líder más popular de la izquierda brasileña en su historia. Vale observar tres fenómenos en este sentido: a) las convocatorias de lucha en torno estas consignas resultaron particularmente bajas si se tiene en cuenta la gravedad de la cuestión y el avance de las fuerzas políticas de derecha en el contexto nacional y latinoamericano; b) los posicionamientos de clase emergieron tibiamente y como calificadores de los orígenes de Lula, antes que como caracterizadores de una política en contradicción abierta con los intereses de la burguesía brasileña y el imperialismo; y c) las luchas contra la desigualdad y la discriminación étnica y de género, y los conflictos en torno al precio del transporte, la democratización interna de las universidades y el acceso a mejores condiciones en los comedores universitarios actuaron más como un factor de dispersión y atomización que como elementos integradores y aglutinadores de luchas políticas más amplias.

Finalmente, podemos observar que el estudiantado universitario, más que expresar una capa social con mayores niveles de activismo y movilización, reflejó la despolitización y la apatía de los sectores populares que se alinearon con el PT. De este modo, el propio accionar político de la dirigencia petista obturó el involucramiento de quiénes podían participar en la defensa de los líderes y una 


\section{Fernando Romero Wimer - Paula Fernández Hellmund}

fuerza política que -más allá de las prácticas antipopulares- se identificaban con la izquierda.

\section{Bibliografía}

Allan Kenji Seki y Olinda Evangelista. "Reforma Universitária no governo Lula. 0 que queriam os industriais". Trabalho necessário. Rio de Janeiro, UFF, $\mathrm{N}^{\circ} 23$, 2016, pp. 67-93.

Andrew Jennings, Raquel Rolnik y Antonio Lassance. Brasil em jogo. O que fica da copa e das olimpíadas. São Paulo, Boitempo, 2014.

Carla Montuori Fernandes, Talita Lucarelli Moreira y Thamiris Franco Martins. "Ativismo, comunicação e política: a voz das ruas em 2013 e o discurso político no HGPE em 2014". IX Simpósio Nacional ABCiber, PUC, 2016.

Cidara Loguercio Souza y Maria Elly Herz Genro. "Memorias de académicos del sur de Brasil en perspectiva de un 'ideal universitario en América': otro legado de los estudiantes?", ponencia presentada en VII Jornadas de estudio y reflexión sobre el movimiento estudiantil argentino y latinoamericano, Facultad de Humanidades y Ciencias. Universidad Nacional del Litoral, Santa Fe, 31 de mayo y $1^{\text {o }}$ de junio de 2018.

Dilma Rousseff. "Presidenta Dilma defende manifestações pacíficas 'A voz da rua tem que ser escutada". 18 de junio de 2013. Disponible en: https://www.youtube.com/watch?v=ENqoHRdV77E [Consulta: 03/10/2018].

Dilvo Ristoff. "O novo perfil do campus brasileiro: uma analise do perfil socioeconómico do estudante de graduação". Avaliação: Revista de Avaliação da Educação Superior. Sorocava, Vol. 19, N³, 2014, pp. 723-747.

Fábio Luciano Oliveira Costa. Financeirização do Capital no Ensino Superior Privado com fins lucrativos no Brasil (2007-2012). Tesis de doctorado. Programa de Posgrado en Educación. Universidade de São Paulo, 2016.

Fabio Luís Barbosa dos Santos. Além do PT. A crise da esquerda brasileira em perspectiva latino-americana. São Paulo, Elefante, 2016.

Fernando Emmendoerfer de Castro. "As manifestações brasileiras de 2013 sob a ótica do HGPE dos candidatos a presidente do Brasil em 2014", Curitiba, UFPR, 2016 (Tesis de Maestría).

Fernando Gabriel Romero, Iván Grasso y Eugenio Monforte. "El movimiento estudiantil universitario bahiense desde el segundo gobierno de Menem a la caída de De la Rúa (1995-2001)”, en Pablo Bonavena, Juan Sebastián Califa y Mariano Millán (Compiladores). El movimiento estudiantil argentino. Historias con presente. Buenos Aires, Ediciones Cooperativas, 2007.

Fernando Gabriel Romero. "Sobre los estudiantes universitarios y movimiento estudiantil: problemas teóricos conceptuales", en Fernando Gabriel Romero (Compilador). Los estudiantes. Organizaciones y luchas en Argentina y Chile. Bahía Blanca, Ediciones en Colectivo, 2009. 


\section{La União Nacional dos estudantes (UNE) ante el juzgamiento y la prisión de Lula da Silva}

Fernando Haddad. "Ruas rebeldes I Fernando Haddad: a catarse e a ressaca política”, 23 de julio de 2017, em: https://www.youtube.com/watch?v=3qXnX2nglY0 [Consulta: 03/10/2018].

Folha de São Paulo, "Lula diz que foi precipitado considerar atos de 2013 democráticos". Folha de São Paulo. São Paulo, 11 de agosto de 2017. Disponível em: https://www1.folha.uol.com.br/poder/2017/08/1909354-lula-diz-quefoi-precipitado-considerar-atos-de-2013-democraticos.shtm [Consulta: 20/09/2018].

Glenda Mezarobba. "Entre reparações, meias verdades e impunidade: o difícil rompimento com o legado da ditadura no Brasil”. Sur, São Paulo: Vol. 7, N 13, diciembre de 2010, pp. 7-25.

João Bernardo y Luciano Pereira. Capitalismo sindical. São Paulo, Xamã, 2008.

João Feres Junior, Verônica Toste Daflon y Luz Augusto Campos. "Ação afirmativa, raça e racismo: uma análise das ações de inclusão racial nos mandatos de Lula e Dilma". Revista de Ciências Humanas. Viçosa, Vol. 12, № 12, julio-diciembre de 2012, pp. 399-414.

Jordana de Souza Santos, "A repressão ao movimento estudantil na ditadura militar". Revista Aurora, Marília, Vol. 3, n 1, 2009, pp. 101-108. Disponible en: http://www.bjis.unesp.br/ojs-

2.4.5/index.php/aurora/article/view/1224/1091 [Consulta: 30/04/2018]. José Carlos Mariátegui. Siete ensayos de interpretación sobre la realidad peruana. Buenos Aires, El Andariego, 2005 [1928].

José Dirceu y Vladimir Palmeiras. Abaixo a ditadura. 0 movimento de 68 contado por seus líderes. São Paulo, Garamond, 1998.

Julio Fisherman, "La ofensiva golpista y la tímida respuesta de los movimientos populares en Brasil", Iberoamérica Social. Revista-Red de Estudios Sociales, Sevilla, Año 5, $\mathrm{N}^{\circ} \mathrm{X}$, junio de 2018, pp. 32-34.

KROTON EDUCACIONAL S.A. "Histórico". Disponible en: http://www.kroton.com.br/ [Consulta: 12/06/2018].

León Trotsky, "La intelligentsia y el socialismo" [1910], en: León Trotsky, Literatura y revolución. Escritos sobre arte y cultura, escritores y crítica literaria. Buenos Aires, Antídoto, 2004.

Luis Bilbao. PT Brasil. Una respuesta latinoamericana al desafío imperialista. Buenos Aires: Búsqueda, 1990.

Luis Henrique Romagnoli y Tânia Gonçalves. A volta da UNE. De Ibiúna a Salvador. São Paulo, Alfa-Omega, 1979.

Luiz Antônio Cunha. A Universidade Temporã: o ensino superior, da Colônia à Era Vargas. São Paulo: Editora UNESP, 2007, $3^{\circ}$ ed.

Marcela Fernandes, "UNE admite que Dilma pode não voltar e discute novas eleições, diz presidente da entidade", em: Huffpost, 19 de mayo de 2016. Disponible en: https://www.huffpostbrasil.com/2016/05/19/une-admite-quedilma-pode-nao-voltar-e-discute-novas-eleicoes-d a 21682553/ [Consulta: 


\section{Fernando Romero Wimer - Paula Fernández Hellmund}

30/05/2016].

María Victoria Espiñeira y Cláudio André de Souza. "Mobilizações dentro e fora das ruas: uma análise dos ciclos de protesto do movimento estudantil brasileiro nas últimas três décadas", ponencia presentada en el $18^{\circ}$ Congresso Brasileiro de Sociologia. Brasilia, 26 a 29 de julio de 2017.

Marta Harnecker. El sueño era posible. Los orígenes del Partido de los Trabajadores de Brasil narrados por sus protagonistas. La Habana: Cultura Popular, 1994, pp. 32-38.

Marta Harnecker. Los conceptos elementales del materialismo histórico. México, Siglo XXI, 1999 [1971], pp. 127-132.

Natalia Gomes dos Reis Dutra y Maria de Fátima de Souza Santos. "Assistência estudantil sob múltiplos olhares: a disputa de concepções". Ensaio. Avaliação e Politicas Públicas em Educação. Rio de Janeiro, Vol. 25, № 94. Enero-marzo de 2017, pp. 148-181.

Noria Segatto, "Frente Brasil Popular, a defesa de Petrobrás e os interesses internacionais em disputa", Movimento dos Trabalhadores Rurais Sem Terra, 30 de septiembre de $2015 . \quad$ Disponible en: http://www.mst.org.br/2015/09/30/frente-brasil-popular-a-defesa-dapetrobras-e-os-interesses-internacionais-em-disputa.html

[Consulta: 20/09/2018].

PARTIDO DOS TRABALHADORES (PT). "Assista: presidenta da UNE defende a candidatura de Lula", 4 de agosto de 2018. Disponible en: http://www.pt.org.br/assista-presidenta-da-une-defende-a-candidatura-delula/ [Consulta: 17/10/2018].

PARTIDO SOCIALISTA DOS TRABALHADORES UNIFICADO (PSTU). STF nega habeas corpus e prisão de Lula é decretada. 5 de abril de 2018. Disponible en: https://www.pstu.org.br/stf-nega-habeas-corpus-e-prisao-de-lula-edecretada/ [Consulta: 23/04/2018].

Paul Singer. "O processo econômico", en Daniel Reis (comp.). Modernização, ditadura e democracia: 1964-2010. Rio de Janeiro, Objetiva, 2014, p. 183-231.

Pierre Bourdieu y Jean Claude Passeron. Los estudiantes y la cultura. Barcelona, Labor, 1967.

Raúl Zibechi. Brasil potência. Entre a integração regional e o novo imperialismo. Rio de Janeiro, Consequência, 2012.

-REPÚBLICA FEDERAL DO BRASIL. MINISTERIO DE EDUCACIÓN (MEC). enso de Educação Superior 2016. Principais resultados. Brasilia: MEC-INEP, 2017. Disponible

en: http://download.inep.gov.br/educacao superior/censo superior/documentos /2016/censo superior tabelas.pdf [Consulta: 30/04/2018].

REPÚBLICA FEDERAL DO BRASIL. MINISTERIO DE EDUCACIÓN (MEC). Censo de Educação Superior 2011. Brasilia: MEC-INEP, 2012.

Renata Bars. "UNE, UBES e ANPG assinaram carta contra o ódio e saem em defesa da democracia". UNIÃO NACIONAL DOS ESTUDANTES (UNE), 15 de octubre de 


\section{La União Nacional dos estudantes (UNE) ante el juzgamiento y la prisión de Lula da Silva}

2018 http://www.une.org.br/noticias/une-ubes-e-anpg-assinam-carta-contrao-odio-e-saem-em-defesa-da-democracia/ [Consulta: 17/10/2018].

Roberto Leher. "Educación pública, movimientos sociales y recuperación de la educación en Brasil". Intercambio. Red Sobre Educación Pública en las Américas (SEPA), Año 6, $\mathrm{N}^{\circ}$ 7, abril de 2015, p. 14-16. Disponible en: http://revistaintercambio.org/index.php/INTERCAMBIO/article/view/5 [Consulta: 29/04/2018].

Rubens Valente, Talita Fernandes y Anna Virginia Ballousier. "Na véspera do julgamento a Lula, comandante do Exército diz repudiar a impunidade". Folha de São Paulo, São Paulo, 3 de abril de 2014. Disponible en: https://www1.folha.uol.com.br/poder/2018/04/na-vespera-de-julgamentosobre-lula-comandante-do-exercito-diz-repudiar-impunidade.shtml [Consulta: 30/04/2018].

Ruy Braga. "Precariado e sindicalismo no Brasil contemporâneo: um olhar a partir da indústria do call center". Revista Crítica de Ciencias Sociales, Coimbra, 2014, N 103, pp. 25-52.

Sara Puerta. "Estudantes e movimentos sociais ocupam a câmara de SP há mais de 24 horas", en: UNIÃO NACIONAL DOS ESTUDANTES (UNE), 10 de agosto de 2017. Disponible en: http://www.une.org.br/noticias/estudantes-emovimentos-sociais-ocupam-a-camara-de-sp-ha-mais-de-24-horas/ [Consulta: 23/04/2018].

Severo Salles. La lucha de clases en Brasil (1960-2012). Buenos Aires, Continente, 2013.

Silene de Moraes Freire. "Movimento Estudantil no Brasil: lutas passadas, desafios presentes". Revista Historia de la Educación Latinoamericana, 2012, № 11, pp. 131-146.

Tomás Eon Barreiros y Danilo Amoroso. "Jornalismo estrábico: Veja e a Carta Capital na Cobertura do 'Escândalo do Mensalão'”. Perspectivas de la Comunicación. Temuco, Universidad de la Frontera, Vol. 1, N 1, pp. 120-131.

UNIÃO DA JUVENTUDE SOCIALISTA (UJS). “Marianna Dias: 'A UNE uma grande história de amor ao Brasil'”. 19 de junio de 2017. Disponible en: http://ujs.org.br/index.php/noticias/marianna-dias-a-une-e-uma-grandeprova-de-amor-ao-brasil/ [Consulta: 23/04/2018].

UNIÃO NACIONAL DOS ESTUDANTES (UNE), "UNE se posiciona contra impeachment de Dilma Rousseff", 5 de diciembre de 2015. Disponible en: http://www.une.org.br/noticias/une-se-posiciona-contra-impeachment-dedilma-rousseff/ [Consulta: 17/10/2018].

UNIÃO NACIONAL DOS ESTUDANTES (UNE), "Estudantes contra nova partilha do pré-sal”, 24 de febrero de 2016. Disponible en: http://www.une.org.br/noticias/estudantes-contra-a-nova-partilha-do-presal/ [Consulta: 17/10/2018]. 


\section{Fernando Romero Wimer - Paula Fernández Hellmund}

UNIÃO NACIONAL DOS ESTUDANTES (UNE). “O pré-sal é do Brasil”, 16 de marzo de 2016. Disponible en: http://www.une.org.br/tv-une/o-pre-sal-e-do-brasil/ [Consulta: 17/10/2018].

UNIÃO NACIONAL DOS ESTUDANTES (UNE). "Nota da UNE sobre condução coercitiva de Lula para depoimento da Policia Federal". 4 de marzo de 2016. Disponible en: http://www.une.org.br/noticias/nota-da-une-sobre-conducaocoercitiva-de-lula-para-depoimento-da-pf/ [Consulta: 30/04/2018].

UNIÃO NACIONAL DOS ESTUDANTES (UNE). "Dia de Mobilização em defesa da liberdade de Lula acontece nesta quarta 11". 10 de abril de 2018. Disponible en: http://www.une.org.br/noticias/dia-de-mobilizacao-em-defesa-da-liberdadede-lula-acontece-nesta-quarta-11/ [Consulta: 11/04/2018].

UNIÃO NACIONAL DOS ESTUDANTES (UNE). “UNE e UBES propõem a criação de comitês em defesa da democracia e de Lula". 12 de abril de 2018. Disponible en: http://www.une.org.br/noticias/une-e-ubes-propoe-a-criacao-de-comites-emdefesa-da-democracia-e-de-lula/ [Consulta: 20/04/2018].

UNIÃO NACIONAL DOS ESTUDANTES (UNE). "SP: Ato em defesa da democracia e de Lula acontece na Praça da República". 23 de enero de 2018. Disponible en: http://www.une.org.br/noticias/sp-ato-em-defesa-da-democracia-e-de-lulaacontece-na-praca-da-republica/ [Consulta: 05/05/2018].

Vera Lucia Jacob Chaves y Nelson Cardoso Amaral. "Politica de Expansão da Educação Superior no Brasil: o PROUNI e o FIES como financiadores do setor privado". Educação em Revista. Belo Horizonte, Vol. 32, № 4, octubre-diciembre de 2016. pp. 42-72.

TL13. "TL13 en Brasil: Así se vivió la destitución de Dilma Rousseff”, 31 de agosto de 2016. Disponible en: http://www.t13.cl/videos/mundo/t13-brasil-asi-sevivio-destitucion-dilma-rousseff [Consulta: 03/09/2018].

Recibido: $12 / 05 / 2018$

Evaluado: $15 / 06 / 2018$

Versión Final: 27/07/2018 